INSIGHTS INTO REGIONAL DEVELOPMENT

ISSN 2669-0195 (online) http://jssidoi.org/IRD/

2021 Volume 3 Number 3 (September)

http://doi.org/10.9770/IRD.2021.3.3(4)

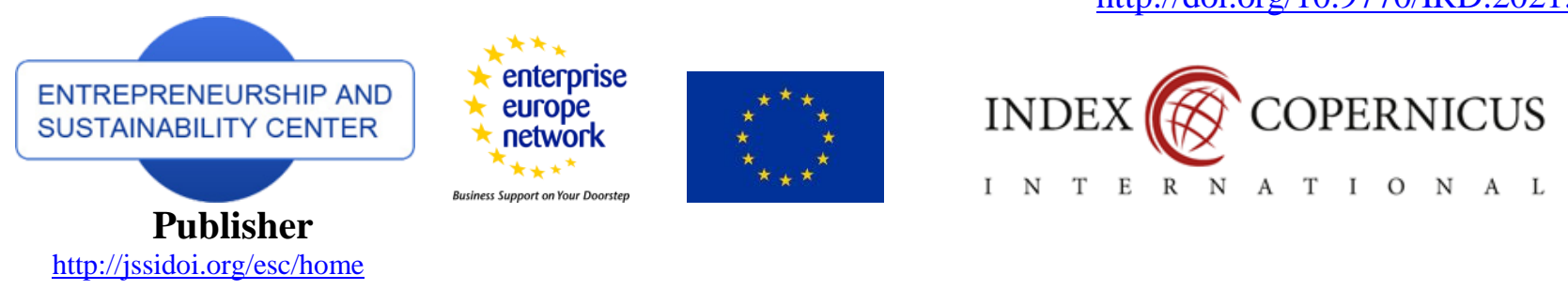

\title{
THE SOCIAL MEDIA USE OF AFRICAN TERRORIST ORGANIZATIONS: A COMPARATIVE STUDY OF AL-QAEDA IN THE ISLAMIC MAGHREB, AL-SHABAAB AND BOKO HARAM
}

\author{
János Besenyő ${ }^{1}$, Gábor Sinkó $^{2}$ \\ ${ }^{1,2}$ Doctoral School of Safety and Secutity Studies, of Óbuda Uniersity, Hungary \\ Emails: ${ }^{1}$ besenyo.janos@uni-obuda.hu; ${ }^{2}$ sinkogabor58@gmail.com
}

Received 15 February 2021; accepted 25 July 2021; published 30 September 2021

\begin{abstract}
The objective of this qualitative study is to raise awareness of the online presence of al-Qaeda in the Islamic Maghreb (AQIM), al-Shabaab and Boko Haram by analyzing and comparing their social media activities. The decision that the above-mentioned terrorist organizations shall be selected for inclusion was based on the fact that (I.) they are active in Africa, (II.) they are currently or affiliated with three of the deadliest international terrorist groups in the continent and (III.) they use social media in order to achieve their goals. I conclude that social media is used by all three of the studied terrorist organizations with special attention devoted to mainstream social media platforms, namely Twitter, YouTube and - to a lesser extent - Facebook. Additionally, AQIM, al-Shabaab and Boko Haram seem to have primarily used social media for propaganda purposes, although it was also utilized as a recruitment tool, albeit to varying degrees. Finally, I believe social media can also be used for coordination and funding by the studied terrorist groups; although the small amount of publicly accessible evidence entails qualitative problems, indicating the fact there is room for further research.
\end{abstract}

Key words: AQIM; al-Shabaab; Boko Haram; terrorism; social media; online messaging; Twitter

Reference to this paper should be made as follows: Besenyő, J., Sinkó, G. 2021. The social media use of African terrorist organizations: a comparative study of Al-Qaeda in the Islamic Maghreb, Al-Shabaab and Boko Haram. Insights into Regional Development, 3(3), 66-78. http://doi.org/10.9770/IRD.2021.3.3(4)

JEL Classifications: D74, F52

\section{Introduction}

The dominance of information and communication technology in Africa has both advantages and disadvantages, since on the one hand it could promote development in the economic, political and social spheres (United Nations General Assembly, 2013), while on the other hand it has the potential to pave the way for the rapid growth of terrorists' use of social media. To illustrate the pace and importance of the latter, between 2000 and 2011, for instance, the number of mobile phone users has grown from 10 million to 647 million people in the continent (Carmody, 2013). Online platforms can provide terrorists with communication, coordination and recruitment tools at relatively low costs. Furthermore, the use of online social media has contributed to the facilitation of sharing propaganda, enlisting potential recruits, coordinating, claiming and/or publicizing terrorist attacks (Cox, K. et. al. 2018). 


\section{INSIGHTS INTO REGIONAL DEVELOPMENT}

ISSN 2669-0195 (online) http://jssidoi.org/jesi/

2021 Volume 3 Number 3 (September)

http://doi.org/10.9770/IRD.2021.3.3(4)

The objective of the study is to raise awareness of the online presence of al-Qaeda in the Islamic Maghreb (AQIM), al-Shabaab and Boko Haram by analyzing and comparing their social media activities. The decision that the above-mentioned terrorist organizations shall be selected for inclusion was based on the fact that [I.] they are active in Africa, [II.] they are currently or affiliated with three of the deadliest international terrorist groups in the continent (Institute for Economics and Peace, 2020) and [III.] they use social media in order to achieve their goals.

Analyzing the links between the terrorist groups' use of social media may lead to a more comprehensive understanding of policymakers in the governmental and institutional spheres, which is likely to facilitate the development of their counter-terrorism policies. International cooperation is required, since AQIM, al-Shabaab and Boko Haram cannot be considered as regional organizations, but are rather interwoven in international terror trends, which are attested by their relations to other terrorist groups. Through careful analysis of the groups' online media statements and video recordings, not only may we be able to predict upcoming attacks in SubSaharan Africa but also put an end to them at an early stage (Ogbondah and Agbese, 2018). Understanding the potential linkages between these terrorist organizations' use of social media can help us formulate more efficient strategies to combat their influence. Scrutinizing online messaging could be instrumental in a sense that the more knowledge we possess, the more fully we will be able to understand terrorist groups' motivations behind committing acts of terrorism.

The study adopts the qualitative research approach and is based on the application of various methods, including reports, former social media analyses and previously-conducted key informant interviews, document content analyses of open source, peer-reviewed academic works and journals. Additionally, despite of them being fragmentary or even politicized, media articles have been analyzed with the intention of painting a clearer image.

\section{The Social Media Use of Al-Qaeda in the Islamic Maghreb (AQIM)}

Since its foundation in 1998, the Salafist Group for Preaching and Combat in Algeria, which has become known based on its French acronym GSPC (Groupe Salafiste pour la Prédication et le Combat), has proved to be quite underperforming in terms of communication (Torres-Soriano, 2010). It is then not surprising that after pledging allegiance to al-Qaeda and changing its name to al-Qaeda in the Islamic Maghreb (AQIM) in 2007, the Islamist militant organization has been working towards positively influencing both the quality and quantity of its propaganda. The GSCP can be considered as a relative latecomer in regards to realizing the strategic opportunities that social media sites had to offer. Not until 2005 did the Algerian terrorist faction see a dramatic increase in its number of online messages; a trend that seemed to have further intensified after the group's affiliation to al-Qaeda and following its communication model (Torres-Soriano, 2016)

In spite of becoming intertwined in the domain of social media, AQIM remained to have a rather local focus, criticizing the role of traditional media in both distorting and undermining the image of the terrorist organization. For instance, the group complained about the ineffectiveness of its messages among Algerian Muslims, whom they claimed were "anaesthetized" by "football matches" (AQIM, 2010). The organization was also plagued by difficulties about its lack of control and centralization of public messages. Although the consequences of such miscomprehensions were often attributed to the "tricks of the Algerian intelligence" (AQIM, 2011); the credibility of its representatives and the denial of particular statements in the name of the terrorist group constituted serious problems in the leadership. The more directions information was disseminated from, the more confused their followers were, not to mention this way the organization's opponents could circulate 'black propaganda' (Zelin, 2011). The media wing of AQIM, al-Andalus Media, was destined to function as an authenticity check, hindering members from bypassing forum administrators, distributing communiqués as official messages.

Besides, al-Andalus Media was responsible for the creation of the group's first Twitter account on 16 March 2013. @ Andalus_Media could be considered as the official profile of the media wing due to AQIM's 


\section{INSIGHTS INTO REGIONAL DEVELOPMENT}

ISSN 2669-0195 (online) http://jssidoi.org/jesi/

2021 Volume 3 Number 3 (September)

http://doi.org/10.9770/IRD.2021.3.3(4)

confirmation on a jihadist Internet forum almost two weeks later. With the intent of intensifying its online messages' impact but also following in the footsteps of al-Qaeda, the group set up an 'open meeting' platform, where it was possible to put questions to Abu Abdul Ilah Ahmed, the leader of the al-Andalus Institute for Media Production. While these could be submitted in French, Spanish, English and Arabic, they were only answered in the latter two languages. In response to identifying Twitter's role in jihad the Sheikh claimed that since the terrorist group belonged to this world they wished to reap the benefits of all the means that facilitated achieving their objectives.

Al-Andalus Media also played a pivotal role in making communication easier with the terrorist organization's followers and sympathizers on Twitter. For example, on March 282013 an advertisement for the media wing of AQIM was created by a formal user belonging to al-Qaeda Central and then later published on several jihadist Internet forums. A couple of days after its becoming accessible, an 'open interview' was organized on the forums, where similarly to an 'open meeting', questions could be asked in the given languages within a specific time frame (Prucha and Fisher, 2013). On April 18, a link pointing to a pdf document appeared on the official Twitter profile of AQIM including the answers of the head of al-Andalus Media Board."

Rather than being an innovation, the model of 'open meetings and interviews' could only be seen as a copy of alQaeda and other jihadist groups. For the most part, Twitter remained to be traditionally used by al-Andalus Media to share photos and texts coupled by particular hashtags. As a result, it could be regarded as "the exclusive channel for the distribution of new propaganda communiqués" (Torres-Soriano, 2016, p. 974). In fact, the majority of AQIM's social media messages were circulated on this account, gaining the group more than 15.000 followers. For instance, 25 public messages were distributed here during the time of its being active in 2013 as opposed to 14, disseminated on various jihadist Internet forums. Nevertheless, in compliance with regulations in terms of the length of tweets, AQIM resorted to sharing links leading to different anonymous websites used for file hosting such as Twitmail.com and JustPaste.it. (Ibid.)

In April 2013, another Twitter account, 'Africa Muslima', was created together with a blog and a Facebook account of the same name. The latter two quickly became dysfunctional due to the lack of updates and suspension respectively, hence Twitter remained the only social media site where the terrorist organization was able to disseminate its propaganda messages. The terrorist organization's preference of the microblogging service can be explained by Twitter's user-friendly interface as well as its appropriate functionality despite weak Internet connection. More importantly, however, Twitter was "far worse than the rest with regard to acting proactively to track and remove terrorist content" (Ogunlana, 2019, p. 84).

Africa Muslima was created with the specific purpose of introducing a wider range of topics with its propaganda messages that were quite different from the communiqués of the group's media wing content-wise. It was "an open platform for every Muslim" destined to provide "support and cooperation to the cause of the Muslim nation generally and African [nation] in particular" (AQIM, 2013). While initially this second Twitter account dealt with the publication of links to file-hosting sites, replacing the functions of the blog that had become outdated in the meantime, later there was a transition to sharing longer texts. Therefore I would argue that Africa Muslima preserved its 'blog-like nature' considering that over half of its texts were over four pages in length. What's more, one did not have to become a member of the terrorist organization to publish here, which is attested by the authors' personal Twitter profiles that 'merely' signaled jihadist activism. ${ }^{\dagger}$

\footnotetext{
* The questions and answers can be accessed here: www.ia801703.us.archive.org/11/items/answersI.1/answersI.pdf (Last accessed: 25.11.2020.)

$\dagger$ For instance @elmohajir_stated the following: ‘Crusades did not end!', www.almeshkat.net/vb/showthread.php?tD28576\#gsc.tabD0, 25 September 2014 (Last accessed: 25.11.2020.)
} 


\section{INSIGHTS INTO REGIONAL DEVELOPMENT}

ISSN 2669-0195 (online) http://jssidoi.org/jesi/

2021 Volume 3 Number 3 (September)

http://doi.org/10.9770/IRD.2021.3.3(4)

Furthermore, in order to make a clear distinction between itself and AQIM's official Twitter account, Africa Muslima decided to create identical graphic display accompanied by a separate logo, making use of various backgrounds, colors and fonts (Al-Jijili, 2013). On top of that, instead of relying heavily on textual materials they included photos in almost third of their communiqués (27\%), which was in sharp contrast with the percentage of online social media messages of al-Andalus Media that had embedded pictures (5.5\%). Another difference between the first and second Twitter profiles of the group was their disparate focus. While al-Andalus Media stressed the importance of collectivism in terms of authorship and only signed $37.3 \%$ of their publicly disseminated messages, this rate was significantly higher (88\%) for Africa Muslima, where the emphasis was placed on individualism (Torres-Soriano, 2016)

Nonetheless, it was the content of its social media messages that differentiated Africa Muslima from al-Andalus Media, since the nature of its tweets was rather peculiar, including themes such as jihadist poetry (Amal, 2013). On the other hand, in contrast to the media wing of AQIM, the group's second Twitter account could deal with matters that were perceived to be less influential and relevant for furthering the terrorist organization's objectives. For instance, there were various topics ranging from a Muslim woman, who had to get rid of her clothes before a security check at an airport in Spain (Al-Maghribi, 22 July 2013) through shutting down a Moroccan Qur'anic school (Al-Maghribi, 4 July 2013) to demonstrating interest in the fate of Salafist prisoners in Morocco. I would reason it is quite intriguing to see that Africa Muslima devoted special attention to Moroccan issues, which seems to be justifiable by the fact that more than $27 \%$ of its publicly disseminated messages contained the name of the country as opposed to the percentage of AQIM communiqués outside the microblogging service $(6 \%)$ (TorresSoriano, 2016, p. 975).

On 18 December 2013 Twitter suspended the accounts of al-Andalus Media and Africa Muslima. Possibly dissatisfied with the impact of its social media messages, AQIM decided to create two similar Twitter profiles in May 2014, which were also suspended in a half year's time. Not until July 2015 did the terrorist organization reappear on Twitter, since in the meantime AQIM sought alternative avenues for circulating its propaganda messages to jihadist Internet forums. Instead of creating a social media profile outside Twitter, preference was given to websites where administrators did not remove their contents, namely archive.org, a digital storehouse and dailymotion.com, a video sharing platform ${ }^{\S}$. However, AQIM's resurgence of interest in Twitter could be explained by the group's intention to communicate with followers and sympathizers, share its online messages and in general take advantage of the speed of distributing information to large audiences. It is important to mention, though, that benefitting from its presence on online media was getting increasing difficult in 2015 after Twitter had adopted a strict policy about suspending profiles connected to jihadist terrorism.

\section{The Social Media Use of Al-Shabaab}

In contrast to AQIM, al-Shabaab could be considered as one of the forerunners of using the Internet to achieve their operational and political goals (Menkhaus, 2014). Since its foundation in 2006, the terrorist organization has strengthened its online presence with the group's social media messages striving to attract the local people living in Somalia, members of the Somali diaspora and the media worldwide. Social media sites have been taken advantage of by al-Shabaab for a variety of reasons, including disseminating propaganda, recruiting sympathizers and followers as well as securing funding and coordinating activities. Although it has profiles and accounts on different media platforms, the jihadist fundamentalist group has the most dominant online presence on YouTube, Twitter and al-Kata'ib, which latter belongs to the media wing of al-Shabaab and can therefore be regarded as its own news channel (Anzalone, 2010).

\footnotetext{
\$www.archive.org/details/@ prodisicilia\#uploads (Last accessed: 25.11.2020.)

$\S$ www.dailymotion.com/AQIM_AQMI [No longer available]
} 


\section{INSIGHTS INTO REGIONAL DEVELOPMENT}

ISSN 2669-0195 (online) http://jssidoi.org/jesi/

2021 Volume 3 Number 3 (September)

http://doi.org/10.9770/IRD.2021.3.3(4)

The focal points for the terrorist organization have gone through dramatic changes ${ }^{* *}$ (Cox, K. et. al. 2018). Initially the emphasis was placed on publishing media reports and the dominance of written, textual messages characterized the group's online activities. Later, however, there was a transition to videos with more graphic content that aimed to facilitate the recruitment of young soldiers from either the Somali diaspora or the West. American-born Abu Mansoor al-Amriki a.k.a. Omar Hammami became the internationally-recognized face of many recruitment and propaganda videos and rap songs encouraging Westerners to join the ranks of the jihadist movement (McKellogg, 2012).

In 2009, al-Shabaab pledged allegiance to al-Qaeda in their first high-definition video titled 'We are at your service, O' Osama'. Following the bay'ah, graphic recordings about the terrorist group's operational tactics and enlistment were continuously released (Meleagrou-Hitchens, 2012). Furthermore, the media wing of the Somali organization was renamed from 'media department' to 'al-Kata'ib Media Foundation' in July 2010, which coupled with the former strategy, signals the objective of the extremist Islamist militia to work towards ongoing recruitment and getting not only local but international publicity. Hence the rebranding of its media department could also be linked to the group's intention to depict it as a legitimate news agency that is likely to be referred to by reporters and journalists worldwide.

Since 2011 al-Shabaab has been increasingly active on Twitter, where according to a former content analysis radical extremist communiqués and propaganda messages were circulated. With the intention of being in the limelight of international media, narrating the occurrences firsthand and thereby shifting the world's focus from the official statements issued by the Kenyan government, the terrorist group decided to microblog a complete real-time coverage on Twitter for the first time when it attacked the Westgate shopping mall in Nairobi in 2013 (Mair, 2016). In fact, the vast majority of the organization's tweets (541 out of 556 textual messages amounting to 97.3\%) found on its Twitter profile were written in English, which also demonstrates the importance of international opinion for the militia (Mair, 2017). Real-time reporting proved to be such an effective tool that the group also used it during its attack on the Makka al-Mukarama hotel in March 2015 and its Lido Beach, Mogadishu attack in January 2016.

However, due to the growing number of strict policies adopted by Twitter about the suspension of jihadist terrorist accounts, al-Shabaab had to create several profiles on the microblogging service. In 2011, the organization signed up for its first official account, @HSMPress, which was the abbreviation of Harakat AlShabaab Al Mujahideen Press Office. By the end of the year the fundamentalist movement had shared more than 50 tweets and gained almost 2500 followers, using its own English and Arabic profiles. The content of the group's social media messages varied greatly, including links to YouTube videos, photos and public statements. Al-Shabaab used Twitter as a means of communication with its followers, notifying them about the execution of a French soldier as retaliation for their rescue attempt. The organization shared a photo of a white man in his military gear, whose identity was later confirmed as Captain Patrice Rebout, a commando of the DGSE (Direction Générale de la Sécurité Extérieure) (Groizeleau, 2013). In revenge for the raid, the Somali movement also issued a statement on Twitter about killing Denis Allex, who the operation was designed to free.

After the English account had been suspended in January 2013, al-Shabaab created another Twitter profile under the name of @HSMPress1 that remained to be operational until September that year. Following its closure the terrorist group established another account, @HSM_Press, through which live messages were disseminated during the Westgate shopping mall attack (Alexander, 2013). Moreover a profile named HSM_INFO was thought to belong to al-Shabaab, which came into being in December 2013, as well as two different accounts that the Islamist militia used when they posted real-time tweets about the Makka al-Mukarama hotel attack in 2015 and the Lido Beach attack in Mogadishu in 2016 (Mohamed, 2013).

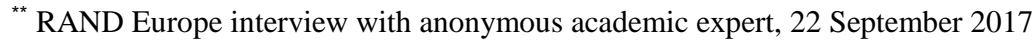




\section{INSIGHTS INTO REGIONAL DEVELOPMENT}

ISSN 2669-0195 (online) http://jssidoi.org/jesi/

2021 Volume 3 Number 3 (September)

http://doi.org/10.9770/IRD.2021.3.3(4)

Besides the promotion of their activities on social media sites, al-Shabaab has formulated criticism against the African Union Mission in Somalia (AMISOM), the local government and the West as well ${ }^{\dagger \dagger}$ (Cox, K. et. al. 2018). For instance, analyzing its media productions on YouTube, one can see that the terrorist organization is primarily preoccupied with uploading content related to the success of its attacks and the training of the group's members (Menkhaus, 2014). On top of that, the quality and style of these video recordings have improved a lot, since the initially grainy, second-rate footages were gradually replaced by more sophisticated ones. Since the creation of the al-Kata'ib Media Foundation in 2010, Kenya, Ethiopia, the U.S., Burundi and Uganda have been in the crosshairs of the extremist Islamist militia's online messages due to their military involvement in Somalia. As a matter of fact civilians of the latter two countries have been pressurized the most in order to achieve the military withdrawal of these countries from AMISOM.

In June 2010, for example, al-Shabaab released a propaganda video under the name of 'The African Crusaders: Fighting the West's War' that documented the Burundian and Ugandan casualties, stating that all their sufferings have been in the 'West's' interests. Another media production with a more significant international resonance was 'An Eye for an Eye', which criticized the actions of Great Britain against Muslim communities all over the world and simultaneously urged lone wolf terrorists to commit similar acts in the West to the 2013 murder of Lee Rigby (Anzalone, 2020). To complement the effect of its graphic content, al-Shabaab also published its online magazines, such as 'Gaidi Mtaani', which can be translated as 'Terrorists on the Street'. This propaganda tool was rather aimed at the youth and could be accessed online in pdf. form ${ }^{+*}$ (Anderson and McKnight, 2015)

Al-Shabaab shared YouTube videos not only for propaganda, but also for recruitment purposes. Online recordings were mostly featured on al-Kata'ib and various sympathetic news channels, such as Calamada and Somalimemo encouraging Muslims to come back to Somalia and take up arms against the 'new crusaders' (Anzalone, 2016). Furthermore, the terrorist group published graphic and written contents including decrees, documents on religious ethics, threats and videos on its official online platform. Although the radical Islamist movement had a dominant presence on YouTube between 2007 and 2009, many of their recruitment videos have been removed since then as they did not comply with the policies of the video-sharing platform.

Communication with the group's to-be recruits and followers also took place in online chatrooms, where alShabaab had the chance to conduct private conversations with these individuals instead of engaging with them on Facebook or Twitter. Regarding the recruitment of the Somali diaspora one can see that the terrorist organization often sought the opinion of the group's commanders about current military operations as well as the role of the diaspora members in enlisting additional fighters (Menkhaus, 2014). These efforts from 2009 to 2013 seem to have come to fruition, since hundreds of individuals from the Somali U.S. and European diasporas decided to join the ranks of al-Shabaab (Pantucci and Sayyid, 2013). With the dissemination of its textual and graphic messages, the militia's online recruitment measures mainly concentrated on Swahili communities as it can be witnessed by the growing number of Kenyan Swahili speakers in the group's recruitment clips since 2013 (Anzalone, 2016). Based on interviews conducted with former al-Shabaab members it turned out technology also played a crucial role in motivating recruitment as a promise of a monthly-paid $\$ 50$ and handing out mobile phones could convince the youth to join the jihadist movement (Federal Republic of Somalia, 2016).

I would argue there have been significant changes in al-Shabaab's use of social media in recent years, which may be seen as a consequence of the numerical increase of Somali internet users. The dominance of Twitter and to a lesser extent Facebook could be explained by the intent of the terrorist organization to be in contact with the locals who were active on the Internet. According to the 2019 data of Internet World Statistics, 98\% of the internet users are subscribers on social media platforms. Nevertheless, the percentage of Somalis with Internet

\footnotetext{
†† RAND Europe interview with Uyo Salifu, academic expert, 18 September 2017, In: Cox, K. et. al, 2018

$\$$ The issues can be accessed at https://sites.google.com/site/islam201407260145/miscellaneous-files/gaidi-mtaani-english-magazine (Last accessed: 25.11.2020.)
} 


\section{INSIGHTS INTO REGIONAL DEVELOPMENT}

ISSN 2669-0195 (online) http://jssidoi.org/jesi/

2021 Volume 3 Number 3 (September)

http://doi.org/10.9770/IRD.2021.3.3(4)

access in the overall population is still relatively low (10.7\%) (Internet World Stats. 2020), hence besides its social media campaigns al-Shabaab often uses a separate radio station, Radio Andalus, to reach individuals in the most remote areas of the country.

Moreover, al-Shabaab has arguably been successful in raising funds by making it possible for the terrorist organization to create ties to rich Salafi networks that were willing to aid the jihadist movement financially (Agbiboa, 2014). For instance, a fundraiser was organized on one of the group's online forums in August 2009 with the purpose of collecting money for fighters in various Somali regions, including Bakool, Gedo and Hiran. By the end of the second week, the diaspora had donated more than $\$ 40.000$ to al-Shabaab, whose leaders demanded all the cash arrive in the country through an informal money transfer system, hawala, reaching the group's contact person in the end, who was located in Mogadishu (Monitoring Group on Somalia. 2010). This example shows that the Internet could also be utilized for raising funds by the terrorist organization.

Nonetheless, al-Shabaab's use of social media for coordination proved to be less effective. It can be explained by the large-scale expansion of the Internet that paved the way for the decentralization of the terrorist organization's online messaging due to the inability of the group to prevent 'unwanted' propaganda or illegitimate posts and tweets on Facebook and Twitter. Although initially the circulation of propaganda had been kept in check with passwords, after the Internet becoming more widely used there was practically nothing that held back independent jihadists from sharing content under the name of the radical Islamist militia, leading to al-Shabaab's loss of control over its online messaging (Menkhaus, 2014).

\section{The Social Media Use of Boko Haram}

Due to the swift expansion of Internet access in Nigeria since 2010, the overall audience of Boko Haram has undergone some fundamental changes. Possibly the most intriguing of these modifications was the terrorist group's ability to expand its geographic reach through reliance on the World Wide Web. It has been reported that a threefold increase could be witnessed in terms of Nigerian Internet usage in case we compared data in 2012 and 2015 (Kazeem, 2016). Besides, in 2012 only 13\% of the terrorist group's messages were published on YouTube and Twitter as opposed to three years later, when all of them could be accessed online.

The abrupt increase in Boko Haram's use of social media coincides with pledging bay'ah to ISIL and becoming the Islamic State West Africa Province, which was followed by the creation of the group's own media department, the Media Office of West Africa Province (MOWAP). Since then, the terrorist organization has been more active on Twitter, YouTube and Facebook (Olawale, 2013) and it has placed greater emphasis on disseminating recording of higher quality and production style. However, there has not been a change in the main content of the group's online messages, as they have continued to publish material about the successes of their current operations and beheadings of hostages (Mahmood, 2017).

It seems Boko Haram primarily uses social media as a propaganda tool, which is attested by the similarities of its online propaganda to ISIL. For instance, the anthem of Islamic State, 'My Umma, Dawn has Arrived' can be increasingly heard in the background when watching video clips of the Nigerian jihadist terrorist group. Furthermore, after declaring allegiance to ISIL in 2015, the logo of Boko Haram went through some changes as the previous flag containing the Qur'an and crossed guns was complemented with the jihadist black flag. In one recording, Abubakar Shekau, the current leader of one of Boko Haram's wings announced that he was founding his separate 'Islamic Caliphate' and greeted all his 'brothers' fighting in Yemen, Somalia, Afghanistan and Pakistan (Olawale, 2013).

Not only do Boko Haram's high-quality video footages bear resemblance to ISIL, but also the tendency to publish violent content and frequently add Arabic and English subtitles to their recordings (BBC News, 2015). In a video 


\section{INSIGHTS INTO REGIONAL DEVELOPMENT}

ISSN 2669-0195 (online) http://jssidoi.org/jesi/

2021 Volume 3 Number 3 (September)

http://doi.org/10.9770/IRD.2021.3.3(4)

posted on YouTube in March 2015, the terrorist group decapitated two Nigerians due to alleged espionage. On the one hand, I would reason that it signals the urge of the organization to share beheading footages online with the public, while on the other hand the application of this 'tactic' mirrors the brutal methods of ISIL. On top of that, since pledging allegiance, a larger number of photos have been posted on the Internet either about the involvement of 'cub' soldiers or Boko Haram fighters being engaged on the Gambaru front. The former aspect further demonstrated the close ties between the groups, since ISIL has shared numerous pictures and recordings of 'cubs' on Twitter as well as in its own propaganda magazines, such as Rumiyah and Dabiq (Jihadology, 2015).

Probably the best-known example of Boko Haram's use of social media for propaganda purposes is the kidnapping of 276 schoolgirls from Borno state, Nigeria on 14-15 April 2014. After the kidnapping, the terrorist organization shared many low-quality, grainy video footages recorded by hand-held cameras, which reflected the group's primitive media use. In a video posted on 5 May 2014, Abubakar Shekau claimed responsibility for the deed, justifying it on the basis that "Allah instructed [him] to sell them... [he] will carry out his instruction" (BBC News, 2014) as well as "slavery is allowed in [his] religion, and [he] shall capture people and make them slaves" (Lister, 2014). Angered by these statements and the Nigerian government's perceived incompetence to deal with the situation, an international media campaign was organized on Twitter with the hashtag '\#BringBackOurGirls'. It started trending that led to increased awareness worldwide; creating 2.3 million tweets by mid-May and 6.1 million retweets by 2016 (Lamb, 2014; Collins, 2014).

Additionally, recent studies demonstrated the growing influence of social media for Boko Haram to recruit its members. It is in line with the statement given by the former Emir of Kano, Sanusi Lamido Sanusi at the $10^{\text {th }}$ Annual Ramadan lecture in Kaduna. He drew attention to the perception of social media as a driver of radicalization for children and teenagers as well as a tool to engage with the terrorist organization. He stressed the negative effects social media has had on establishing firm ethical values as the youth were becoming largely exposed to and obsessed with social media sites, for instance YouTube, Twitter, Facebook and WhatsApp. It is due to Boko Haram's increased abilities in the online space to either manipulate or negatively indoctrinate them after formulating personal connections or even friendships (Madugba, 2015). In November 2015, the niece of a community leader in Jos decided to personally encounter her boyfriend - whom she had allegedly been in contact with via Facebook - in Maiduguri, Borno state. Sadly, despite extensive searches she hadn't been seen or heard of since then apart from the only piece of information according to which she had been married to one of Boko Haram's unit commanders. A large number of similar stories can be heard about the misguidance of people on social media sites with the intention of subsequently recruiting them (Maza; Koldas; Aksit, 2020).

At the end of January 2015, Boko Haram created four distinct accounts on Twitter under the name of 'al-Urwah al-Wuthqa', which gained 4,000 followers in a matter of days. Although they were all suspended due to policy violation in March 2015, whilst being operational, the group shared photos of the military training of 'cub' soldiers wearing dark robes and holding AK-47 assault rifles. According to the caption of the photos, child soldiers were regarded as the "generation of conquest and victory" (Laing, 2015). Although the images could as well serve propaganda purposes, I would reason there is also a link to recruitment through Boko Haram's intention to influence the highest number of individuals by disseminating instant messages to them. Besides, a specific video link was tweeted by the same account that contained various members of the terrorist organization providing explanations on motivations to join Boko Haram in its fight (Ibid.). As a consequence, I would argue that Twitter was used with the explicit purpose of recruitment with the help of this video; although the terrorist organization's social media use can be regarded as less overt than of al-Shabaab or ISIL for instance. However, this way existing members of the group could convey their messages to large online audiences.

Finally, Boko Haram appears to use social media for the coordination of its activities on social media platforms and the Internet, which is attested by creating tighter links with ISIL. Besides, the terrorist organization's media strategy reflects the one used by the Iraqi and Syrian central leadership (BBC News, 2015). For example, a higher-quality video interview with the group's former spokesperson, Abu Musab al-Barnawi was published on 


\section{INSIGHTS INTO REGIONAL DEVELOPMENT}

ISSN 2669-0195 (online) http://jssidoi.org/jesi/

2021 Volume 3 Number 3 (September)

http://doi.org/10.9770/IRD.2021.3.3(4)

an ISIL media channel on 27 January 2015. Hence, it can be witnessed that even before the bay'ah to Islamic State, the jihadist sect was working towards forging closes ties with the organization, which affected production quality positively. The recording had also been shared on Boko Haram's official Twitter account, al-Urwah alWuthqa, before it was uploaded and circulated on ISIL media sources (Jihadology, 2015).

\section{Conclusion}

Social media is used by AQIM, al-Shabaab and Boko Haram in the African continent. The significance of media communications with regards to the strategic objectives of the terrorist organizations is highlighted by the creation of their specific media wings, such as AQIM's al-Andalus Media, al-Shabaab's al-Kata'ib Media Foundation and Boko Haram's Media Office of West Africa Province. Due to the swift expansion of Internet access in Africa and continuous development in the technological sector, there has obviously been an increase in the social media use of the terrorist groups, depending on their geographical location. After pledging allegiance to al-Qaeda and ISIL respectively, AQIM's, al-Shabaab's and Boko Haram's social media messages have improved dramatically in terms of their quality, quantity and production style.

Analyzing the content of their online messaging, it appears that AQIM and Boko Haram had a rather local focus; concentrating on matters that more directly affected the terrorist groups in furthering their strategic aims, while alShabaab strived to make an impact both locally and internationally. It is attested by AQIM's frequent engagement with Algerian issues, including complaints about the ineffectiveness of messages among Algerian Muslims as well as problems regarding the decentralization of public messages, which was blamed on the Algerian intelligence. Similarly, Boko Haram was mostly engaged with Nigerian matters, for instance, sharing tweets and photos about their operational successes or publishing videos related to the training of 'cub' soldiers or beheading of Nigerian spies. On the contrary, al-Shabaab was not only concerned with the issues of locals and the Somali diaspora, but they also microblogged the complete real-time coverage of the Westgate shopping mall attack in Kenya.

It appears that all three of the studied terrorist groups predominantly used Twitter, Facebook and YouTube. While the first two social media sites were utilized with the intent of sharing texts and images with large audiences (with Facebook being used to a much lesser extent than Twitter), the online video-sharing platform was mostly responsible for disseminating graphic contents. However, in some cases, instead of engaging with potential recruits and followers on mainstream social media platforms, al-Shabaab conducted private conversations with interested individuals in online chatrooms. On top of that, after the repeated suspension of their Twitter accounts AQIM sought alternative avenues for circulating its online messages to jihadist forums, giving preference to websites where administrators did not remove their contents.

First and foremost, AQIM, al-Shabaab and Boko Haram seem to have used social media for propaganda purposes, since these terrorist organizations often boasted about their operational victories, denounced their enemies, published and claimed responsibility for their attacks and displayed rather violent tactics. Additionally, social media was also utilized as a recruitment tool, albeit to varying degrees. The online strategies of AQIM and Boko Haram appeared to be less overt as opposed to the more direct nature of al-Shabaab's use of social media for recruitment. While the first two groups concentrated their efforts on information-sharing through 'open meetings and interviews' (AQIM) and online radicalization via sharing a video in which members explained their motivations to join the organization (Boko Haram), al-Shabaab devoted special attention to answering the questions of to-be recruits in online chatrooms and publicizing their diaspora fighters' testimonies in the form of YouTube videos.

Social media is also believed to be used for coordination and funding; although the small amount of publicly accessible evidence entails qualitative problems. Nevertheless, affiliation to ISIL seems to signal a positive 


\section{INSIGHTS INTO REGIONAL DEVELOPMENT}

ISSN 2669-0195 (online) http://jssidoi.org/jesi/

2021 Volume 3 Number 3 (September)

http://doi.org/10.9770/IRD.2021.3.3(4)

correlation with coordination, while affiliation to al-Qaeda appears to illustrate a negative one. This could be argued, since the online messaging of AQIM and al-Shabaab was growingly characterized by a loss of control and decentralization, but Boko Haram could forge closer ties with ISIL after its bay'ah. Besides, with the exception of al-Shabaab's ability to raise funds by creating ties to rich Salafi networks, the role of these terrorist groups' use of social media in securing funding remains to be explored.

\section{References}

Agbiboa, D. E. 2014. Ties that Bind: The Evolution and Links of Al-Shabab, The Commonwealth Journal of International Affairs, 103(6), pp. 581-597, DOI: $10.1080 / 00358533.2014 .988028$

Alexander, H. 22 September 2013. Tweeting Terrorism: How Al Shabaab Live Blogged the Nairobi Attacks, The Telegraph, https://www.telegraph.co.uk/news/worldnews/africaandindianocean/kenya/10326863/Tweeting-terrorism-How-al-Shabaab-live-bloggedthe-Nairobi-attacks.html (Last accessed: 25.11.2020.)

Al-Jijili, A. 14 June 2013. Did Africa Really Get Its Independence? Africa Muslima, www.twitter.com/Africamuslima/status/345572285593288705 [No longer available]

Al-Maghribi, A. I. 22 July 2013. A New Cry From al-Andalus, www.twitter.com/Africamuslima/status/359423321122684930 [No longer available]

Al-Maghribi, A. I. 4 July 2013. Another Great Achievement in the History of the Emirate of Believers: the Order to Close the Quran Schools, www.twitter.com/Africamuslima/status/353272175404384257 [No longer available]

Amal. 17 July 2013. If You Have Forgotten Me, So What Has Your Lord Forgotten, www.twitter.com/Africamuslima/status/357596580423016449 [No longer available]

Anderson, D. M.; McKnight J. 2015. Understanding Al-Shabaab: Clan, Islam and Insurgency in Kenya. Journal of Eastern African Studies, 9(3), pp. 536-557, DOI: 10.1080/17531055.2015.1082254

Anzalone, C. 2016. Continuity and Change: The Evolution and Resilience of Al-Shabab's Media Insurgency, 2006-2016, Hate Speech International, https://www.hate-speech.org/wp-content/uploads/2016/11/email_722762_Readers.pdf (Last accessed: 25.11.2020.)

Anzalone, C. 2016. The Resilience of Al-Shabaab, CTC Sentinel, 9(4), pp. 13-20, https://ctc.usma.edu/app/uploads/2016/04/CTCSENTINEL-Vol9Iss426.pdf (Last accessed: 25.11.2020.)

Anzalone, C. 2020. Addressing the Enemy: Al-Shabaab's PSYOPS Media Warfare, CTC Sentinel, 13(3), https://ctc.usma.edu/addressingenemy-al-shabaabs-psyops-media-warfare/ (Last accessed: 25.11.2020.)

Anzalone, C. 25 August 2010. From "Martyrdom" Videos to Jihadi Journalism in Somalia: The Rapid Evolution of Harakat al-Shabab alMujahideen's Multimedia, Informed Comment, https://www.juancole.com/2010/08/anzalone-from-\%E2\%80\%98martyrdom\%E2\%80\%99videos-to-jihadi-journalism-in-somalia.html (Last accessed: 25.11.2020.)

AQIM. 19 April 2011. Denial of the Manufactured Dialogue with the Newspaper al-Hayyat al-Londoniyyah, www.aljahad.com/vb/showthread.php?pD12926\#post12926 [No longer accessible]

AQIM. 5 June 2013. Glad Tidings to Our Muslim Ummah: The Muslim Africa Blog, www.as-ansar.com/vb/showthread.php?tD88550 [No longer available]

AQIM. 7 June 2010. Surrender of the Two Brothers is a Lie (Abu Al-Abbas and Abu Nu'Man), www.occident2.blogspot.com.es/2010/06/al-qaida-in-islamic-maghrebissues.html (Last accessed: 25.11.2020.)

BBC News. 5 May 2014. Boko Haram 'to sell' Nigeria girls abducted from Chibok', https://www.bbc.com/news/world-africa-27283383 (Last accessed: 25.11.2020.) 


\section{INSIGHTS INTO REGIONAL DEVELOPMENT}

ISSN 2669-0195 (online) http://jssidoi.org/jesi/

2021 Volume 3 Number 3 (September)

http://doi.org/10.9770/IRD.2021.3.3(4)

BBC News. 4 March 2015. Is Islamic State Shaping Boko Haram Media?, http://www.bbc.com/news/world-africa-31522469 (Last accessed: 25.11.2020.)

Carmody, P. 2013. A Knowledge Economy or an Information Society in Africa? The integration and the Mobile Phone Revolution. Information Technology for Development Journal, 19(1), pp. 24-39, DOI: 10.1080/02681102.2012.719859

Collins, M. 9 May 2014. "\#BringBackOurGirls: the power of a social media campaign", The Guardian, https://www.theguardian.com/voluntary-sector-network/2014/may/09/bringbackourgirls-power-of-social-media (Last accessed: 25.11.2020.)

Cox, K. et. al. 2018. Social media in Africa: A double-edged sword for security and development. RAND. Research report. United Nations Development Programme. Regional Centre for Africa. Cambridge, https://www.africa.undp.org/content/rba/en/home/library/reports/socialmedia-in-africa-.html (Last accessed: 25.11.2020.)

Federal Republic of Somalia. 2016. National Strategy and Action Plan for Preventing and Countering Violent Extremism, http://www.radiomuqdisho.net/wp-content/uploads/2016/08/CVE-Strategy-26-August-English.pdf (Last accessed: 25.11.2020.)

Groizeleau, V. 14 January 2013. Le Mistral au coeur de la tentative de libération de Denis Allex en Somalie, Mer et Marine, https://www.meretmarine.com/fr/content/le-mistral-au-coeur-de-la-tentative-de-liberation-de-denis-allex-en-somalie (Last accessed: 25.11.2020.)

Institute for Economics and Peace. 2020. Global Terrorism Index, https://www.visionofhumanity.org/wp-content/uploads/2020/11/GTI2020-web-1.pdf (Last accessed: 25.11.2020.)

Internet World Stats. 2020. Africa. Somalia, https://www.internetworldstats.com/africa.htm\#so (Last accessed: 25.11.2020.)

Jihadology. 27 January 2015. The Clairvoyant: Boko Haram's Media and the Islamic State Connection?. Jihadology, http://jihadology.net/2015/01/27/the-clairvoyant-boko-harams-media-and-the-islamic-stateconnection [No longer available]

Kazeem, Y. 2016. There aren't as many Nigerian mobile Internet users as we thought, Quartz Africa, http://qz.com/658762/there-arent-asmany-nigerians-on-the-mobile-internet-as-we-thought/ (Last accessed: 25.11.2020.)

Laing, A. 3 February 2015. Twitter Suspends Suspected Boko Haram Account That Tweeted Pictures of Child Soldiers, Daily Telegraph, https://www.telegraph.co.uk/news/worldnews/africaandindianocean/nigeria/11387473/Twitter-suspends-suspected-Boko-Haram-accountthat-tweeted-pictures-of-child-soldiers.html (Last accessed: 29.10.2020)

Lamb, C. 14 May 2014. Find our girls and save their dreams, The Sunday Times, https://www.thetimes.co.uk/article/find-our-girls-andsave-their-dreams-nv60pm9fn06 (Last accessed: 25.11.2020.)

Lister, T. 6 May 2014. Boko Haram: The essence of terror', CNN, https://edition.cnn.com/2014/05/06/world/africa/nigeria-boko-haramanalysis/ (Last accessed: 25.11.2020.)

Madugba, A. 5 July 2015. Kano Emir Links Boko Haram to Social Media, Internet. Vanguard News, https://www.vanguardngr.com/2015/07/kano-emir-links-boko-haram-to-social-media-internet/ (Last accessed: 25.11.2020.)

Mahmood, O. S. 2017. More than Propaganda: A Review of Boko Haram's Public Messages, Institute for Security Studies, West Africa Report 20, https://issafrica.s3.amazonaws.com/site/uploads/war20.pdf (Last accessed: 25.11.2020)

Mair, D. 2017. \#Westgate: A Case Study: How Al-Shabaab Used Twitter During an Ongoing Attack, Studies in Conflict and Terrorism, 40(1), pp. 24-43, DOI: 10.1080/1057610X.2016.1157404

Mair, D. 3 February 2016. Al-Shabaab Returns to Twitter, VOX-Pol, http://www.voxpol.eu/al-shabaab-returns-to-twitter (Last accessed: 25.11.2020.)

McKellogg, J. A. 28 September 2012. American-born jihadi's role shifts in al-Shabab, The Washington Post, https://www.washingtonpost.com/video/world/american-born-jihadis-role-shifts-in-al-shabab/2012/09/28/2bed8c02-098e-11e2-858a-

5311df86ab04_video.html (Last accessed: 25.11.2020.) 


\section{INSIGHTS INTO REGIONAL DEVELOPMENT}

ISSN 2669-0195 (online) http://jssidoi.org/jesi/

2021 Volume 3 Number 3 (September)

http://doi.org/10.9770/IRD.2021.3.3(4)

Maza, K. D.; Koldas, U.; Aksit, S. 2020. Challenges of Countering Terrorist Recruitment in the Lake Chad Region: The Case of Boko Haram. MDPI, Religions, 11(2), 96, Nicosia, DOI: 10.3390/rel11020096

Meleagrou-Hitchens, A. et. al. 2012. 'Lights, Camera, Jihad: Al-Shabaab's Western Media Strategy', International Centre for the Study of Radicalisation and Political Violence, London, https://icsr.info/wp-content/uploads/2012/11/ICSR-Lights-Camera-JihadReport_Nov2012_ForWeb-2.pdf (Last accessed: 25.11.2020.)

Menkhaus, K. 2014. Al-Shabaab and Social Media: A Double-Edged Sword, Brown Journal of World Affairs, 20(2), pp. 309-327

Mohamed, H. 16 December 2013. Al-Shabab Say They Are Back on Twitter, Al-Jazeera, https://www.aljazeera.com/news/2013/12/16/alshabab-say-they-are-back-on-twitter/ (Last accessed: 25.11.2020.)

Monitoring Group on Somalia. 2010. Report of the Monitoring Group on Somalia Pursuant to Security Council Resolution 1853 (2008). United Nations Security Council, https://reliefweb.int/report/somalia/report-monitoring-group-somalia-pursuant-security-councilresolution-1853-2008 (Last accessed: 25.11.2020.)

Ogbondah, C. W.; Agbese, P. O. 2018. Terrorists and Social Media Messages: A Critical Analysis of Boko Haram's Messages and Messaging Techniques, In: The Palgrave Handbook of Media and Communication, edited by B. Mutsvairo, Palgrave Macmillan, Cham, pp. 313-345, DOI: 10.1007/978-3-319-70443-2_18

Ogunlana, S. O. 2019. Halting Boko Haram / Islamic State's West Africa Province Propaganda in Cyberspace with Cybersecurity Technologies, Journal of Strategic Security, 12(1), University of South Florida Board of Trustees, pp. 72-106, DOI: 10.5038/19440472.12.1.1707

Olawale, I. 2013. Radicalisation and Violent Extremism in West Africa: Implications for African and International Security, Conflict, Security and Development, 13(2), pp. 209-230, DOI: 10.1080/14678802.2013.796209

Pantucci, R.; Sayyid A. R. 2013. Foreign Fighters in Somalia and Al-Shabaab's Internal Purge, Jamestown Foundation Terrorism Monitor, 11(22), pp. 4-5, https://jamestown.org/program/foreign-fighters-in-somalia-and-al-shabaabs-internal-purge (Last accessed: 25.11.2020.)

Prucha, N.; Fisher, A. 2013. Tweeting for the Caliphate: Twitter as the New Frontier for Jihadist Propaganda. CTC Sentinel, 6(6), pp. 1923, https://www.ctc.usma.edu/tweeting-for-the-caliphate-twitter-as-the-new-frontier-for-jihadist-propaganda/ (Last accessed: 25.11.2020.)

Torres-Soriano, M. R. 2010. The Road to Media Jihad: The Propaganda Actions of Al Qaeda in the Islamic Maghreb. Terrorism and Political Violence, 23(1), pp. 72-88, DOI: 10.1080/09592318.2016.1208280

Torres-Soriano, M. R. 2016. The Caliphate Is Not a Tweet Away: The Social Media Experience of Al Qaeda in the Islamic Maghreb. Studies in Conflict \& Terrorism, 39(11), pp. 968-981, DOI: 10.1080/1057610X.2016.1159430

United Nations General Assembly. 2013. Group of Governmental Experts on Developments in the Field of Information and Telecommunications in the Context of International Security. A/68/98. https:/www.unidir.org/files/medias/pdfs/developments-in-the-fieldof-information-and-telecommunications-in-the-context-of-international-security-2012-2013-a-68-98-eng-0-518.pdf (Last accessed: 25.11.2020.)

Zelin, A. Y. 4 April 2011. AQIM Statement Hoax?. al-Wasat, www.thewasat.wordpress.com/2011/04/04/aqim-statement-hoax/ (Last accessed: 25.11.2020.) 
INSIGHTS INTO REGIONAL DEVELOPMENT

ISSN 2669-0195 (online) http://jssidoi.org/jesi/

2021 Volume 3 Number 3 (September)

http://doi.org/10.9770/IRD.2021.3.3(4)

János BESENYŐ

ORCID ID: 0000-0001-7198-9328

Gábor SINKÓ

ORCID ID: 0000-0002-6451-8701

Make your research more visible, join the Twitter account of INSIGHTS INTO REGIONAL DEVELOPMENT:

@IntoInsights

Copyright (C) 2021 by author(s) and VsI Entrepreneurship and Sustainability Center

This work is licensed under the Creative Commons Attribution International License (CC BY).

http://creativecommons.org/licenses/by/4.0/

(c) (i) Open Access 